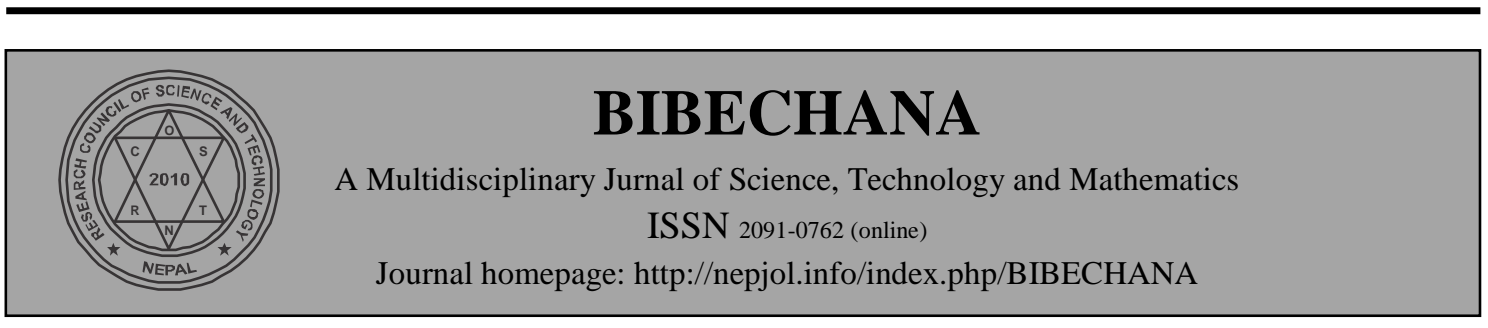

\title{
Management of collar rot of tomato caused by Sclerotium rolfsii
}

\author{
Indramani Bhagat \\ Department of Botany, Post Graduate Campus, Biratnagar \\ Tribhuvan University, Nepal \\ E-mail: drimbhagat@yahoo.com
}

Accepted for publication: February 08, 2014

\begin{abstract}
Collar rot of tomato (Lycopersicum esculentum Miller) caused by Sclerotium rolfsii Sacc. is one of the most destructive diseases in tomato throughout the world. Effective and efficient management of the crop disease is generally achieved by the use of synthetic pesticides. These pesticides are known to pollute the environment, soil and water besides causing deleterious effects on human health and biosphere.

Amendments (Neem cake, oil cake, cow dung, rabbit manure and chicken manure) were used in tomato seedlings to observe growth promotion and percentage increase in shoot length in healthy and treated tomato seedlings of two varieties, $\mathrm{F}_{1}$ Hybrid Arjuna and Pahuza S-22. Results revealed that growth of the tomato seedlings was significantly increased following amendment with neem cake and oil cake in the treated Sclerotium rolfsii inoculated plants than in untreated uninoculated plants as recorded. Oil cake had better effect than neem cake. Similarly, amendment with cow dung, rabbit manure and chicken manure it has been observed that the growth of tomato seedlings increased in treated uninoculated than treated inoculated tomato seedlings. Among the three treatments, cow dung gave better growth of tomato seedlings than that of rabbit manure and chicken manure.
\end{abstract}

(C) 2014 RCOST: All rights reserved.

Keywords: Organic amendment; Pathogen; Manure.

\section{Introduction}

Tomato (Lycopersium esculentum Miller) is one of the second most popular vegetable crops of world. It is attacked by a large number of fungal, viral and bacterial pathogens. Sclerotium rolfsii is one of the important fungal pathogens that causes collar rot resulting in substantial yield losses. This disease appears in the nursery grown tomato seedlings. The fungus is a soil borne rotting pathogen of very aggressive nature and causes considerable damage to young tomato seedlings in the nursery which is very common in the plains but rare in the hills. It occurs in diverse soils, has a very wide host range and worldwide distribution [1].

However effective and efficient management of crop diseases is generally achieved by the use of synthetic pesticides. These pesticides are known to pollute the environment, soil and water besides causing deleterious effects on human health and biosphere. The present investigation is related to the study of the management of collar rot disease of tomato by organic amendments. 
I. Bhagat / BIBECHANA 11(1) (2014) 136-140: (Online Publication: March, 2014) p.137

\section{Materials and method}

\section{Plant material}

Two tomato varieties $F_{1}$ Hybrid Arjuna and Pahuza S-22 were grown in pots and were used for experimental purpose.

\section{Fungal culture}

\section{Source of cultures}

Virulent culture of Sclerotium rolfsii Sacc was obtained from Immuno-Phytopathology Laboratory, Department of Botany, North Bengal University. This was originally isolated from Teen Ali-17/1/54 and after completion of Kock's Postulate, the organism was identified by Global Plant Clinic, Diagnostic and Advisory Service, CABI Bioscience UK and designated as Sr-1.

\section{Maintenance of stock cultures}

The fungus thus obtained has been sub-cultured on PDA slants. After two weeks the culture has been stored under three different conditions $\left(0^{\circ} \mathrm{C}, 4^{\circ} \mathrm{C}\right.$ and at room temperature $\left.28^{\circ} \mathrm{C}\right)$. The culture of $S$. rolfsii was examined at regular intervals to test its pathogenicity.

\section{Effect of organic amendments on tomato seedling in pot culture}

Pot culture experiment were conducted with different organic amendments treated in the tomato seedlings to observe growth promotion and percentage increase in shoot length in healthy and treated tomato seedling varieties. The earthen pots were filled with autoclaved $1 \mathrm{~kg}$ of soil. Mustard oil cakes were allowed to decompose for a week in a clay pot covered with polythene. $100 \mathrm{ml}$ of decomposed oil cake solution, $100 \mathrm{~g}$ powdered neem cake, $100 \mathrm{~g}$ cow dung, $100 \mathrm{~g}$ chicken and $100 \mathrm{~g}$ rabbit manure were added in pots containing sterilized soil separately and watered.

After one week, the seedlings of two varieties of tomato ( $\mathrm{F}_{1}$ Hybrid Arjuna and Pahuza S-22) were grown in soil amended with neem cake, oil cake, cow dung, rabbit and chicken manure separately before inoculation with $100 \mathrm{~g}$ Sclerotium rolfsii and watered lightly. Then these pots were inoculated with the test pathogen multiplied on sand-maize medium and watered lightly. The seedlings were planted in the earthen pots without amendments but inoculated with the pathogen and were maintained as control. Each treatment consisted of 10 plants, in triplicate and the values are an average of 30 plants. The observations were recorded after two months.

\section{Results and Discussion}

Results (Tables 1 \& 2) revealed that the growth of the tomato seedlings was significantly increased following amendment with neem cake and oil cakes in the treated $S$. rolfsii inoculated seedlings than in untreated inoculated seedlings as recorded after two months. Oil cake had better effect than neem cake. It had been observed that the percentage increase in shoot length after two months of treatment with neem cake and oil cake in treated inoculated with $S$. rolfsii the tomato seedlings was more than in the untreated inoculated tomato seedlings. 
I. Bhagat / BIBECHANA 11(1) (2014) 136-140: (Online Publication: March, 2014) p.138

Table 1: Growth promotion in tomato seedlings following soil amendment with neem cake and oil cake

\begin{tabular}{|c|c|c|c|c|c|c|c|c|}
\hline \multirow[b]{3}{*}{$\begin{array}{l}\text { Tomato } \\
\text { variety }\end{array}$} & \multicolumn{4}{|c|}{ One month } & \multicolumn{4}{|c|}{ Two months } \\
\hline & \multicolumn{2}{|c|}{ Healthy } & \multicolumn{2}{|c|}{ Infected } & \multicolumn{2}{|c|}{ Healthy } & \multicolumn{2}{|c|}{ Infected } \\
\hline & $\begin{array}{l}\text { Increase } \\
\text { in height } \\
(\mathrm{cm})\end{array}$ & $\begin{array}{l}\text { Increase } \\
\text { number of } \\
\text { compound } \\
\text { leaves }\end{array}$ & $\begin{array}{l}\text { Increase } \\
\text { in height } \\
(\mathrm{cm})\end{array}$ & $\begin{array}{l}\text { Increase } \\
\text { number of } \\
\text { compound } \\
\text { leaves }\end{array}$ & $\begin{array}{l}\text { Increase } \\
\text { in height } \\
(\mathrm{cm})\end{array}$ & $\begin{array}{l}\text { Increase } \\
\text { number of } \\
\text { compound } \\
\text { leaves }\end{array}$ & $\begin{array}{l}\text { Increase } \\
\text { in height } \\
\mathrm{cm}\end{array}$ & $\begin{array}{l}\text { Increase } \\
\text { number of } \\
\text { compound } \\
\text { Leaves }\end{array}$ \\
\hline $\begin{array}{l}\text { F }_{1} \text { Hybrid } \\
\text { Arjuna } \\
\text { Untreated }\end{array}$ & $29 \pm 1.24$ & $10 \pm 1.01$ & $20 \pm 1.22$ & $7 \pm 0.06$ & $36 \pm 1.35$ & $12 \pm 1.14$ & $34+1.29$ & $9 \pm 0.07$ \\
\hline $\begin{array}{l}\text { Treated } \\
\text { Neem } \\
\text { cake }\end{array}$ & $20 \pm 1.19$ & $7 \pm 0.06$ & $19 \pm 1.18$ & $6 \pm 0.04$ & $32 \pm 1.32$ & $11 \pm 1.17$ & $40 \pm 2.42$ & $13 \pm 1.14$ \\
\hline Oil cake & $23 \pm 1.26$ & $8 \underline{+0.05}$ & $25 \pm 1.23$ & $9 \pm 0.08$ & $58 \pm 2.12$ & $19 \pm 1.19$ & $55 \pm 2.11$ & $18 \pm 1.17$ \\
\hline $\begin{array}{l}\text { Pahuza S- } \\
22 \\
\text { Untreated }\end{array}$ & $28 \pm 1.29$ & $9 \pm 0.02$ & $17 \pm 1.16$ & $6 \pm 0.05$ & $35 \pm 1.34$ & $11 \pm 1.09$ & $32 \pm 1.33$ & $8 \pm 0.02$ \\
\hline $\begin{array}{l}\text { Treated } \\
\text { Neem } \\
\text { cake }\end{array}$ & $19 \pm 1.13$ & $6 \pm 0.03$ & $17 \pm 1.15$ & $5 \pm 0.04$ & $31 \pm 1.30$ & $10 \pm 1.02$ & $30 \pm 1.34$ & $10 \pm 1.09$ \\
\hline Oil cake & $21 \pm 1.21$ & $7 \pm 0.09$ & $23 \pm 1.21$ & $8 \pm 0.07$ & $56 \pm 2.10$ & $18 \pm 1.17$ & $46 \pm 2.01$ & $16 \pm 1.17$ \\
\hline
\end{tabular}

Average of 3 replicates \pm Standard error.

Table 2: Percentage increase in shoot length in tomato seedlings following treatment with neem cake and oil cake

\begin{tabular}{|c|c|c|}
\hline \multirow{2}{*}{ Tomato variety } & \multicolumn{2}{|c|}{ Percentage increase in shoot length after two months treatment } \\
\cline { 2 - 3 } & Healthy & Infected \\
\hline $\begin{array}{c}\text { F }_{\mathbf{1}} \text { Hybrid Arjuna } \\
\text { Untreated }\end{array}$ & 24.14 & 70.0 \\
\hline $\begin{array}{c}\text { Treated } \\
\text { Neem cake }\end{array}$ & 60.0 & 110.0 \\
\hline Oil cake & 163.64 & 120.0 \\
\hline $\begin{array}{c}\text { Pahuza S-22 } \\
\text { Untreated } \\
\text { Treated } \\
\text { Neem cake }\end{array}$ & 93.94 & 25 \\
\hline Oil cake & 63.16 & 73.53 \\
\hline
\end{tabular}


I. Bhagat / BIBECHANA 11(1) (2014) 136-140: (Online Publication: March, 2014) p.139

It revealed that the growth of tomato seedlings had been increased in treated uninoculated than treated inoculated tomato seedlings (Table 3). Among the three treatments, cow dung gave very good and healthy growth of tomato seedlings (Plate 1: Fig. D) than rabbit and chicken manure (Plate 1: Fig. E \& F).

Table 3: Growth promotion in tomato seedlings by different organic components after inoculation with

\section{Sclerotium rolfsii}

\begin{tabular}{|c|c|c|c|c|c|c|c|c|}
\hline \multirow[b]{3}{*}{$\begin{array}{l}\text { Tomato } \\
\text { variety }\end{array}$} & \multicolumn{4}{|c|}{ One month } & \multicolumn{4}{|c|}{ Two months } \\
\hline & \multicolumn{2}{|c|}{ Healthy } & \multicolumn{2}{|c|}{ Infected } & \multicolumn{2}{|c|}{ Healthy } & \multicolumn{2}{|c|}{ Infected } \\
\hline & $\begin{array}{l}\text { Increase } \\
\text { in } \\
\text { height } \\
(\mathrm{cm})\end{array}$ & $\begin{array}{l}\text { Increase } \\
\text { number of } \\
\text { compound } \\
\text { leaves }\end{array}$ & $\begin{array}{l}\text { Increase } \\
\text { in height } \\
(\mathrm{cm})\end{array}$ & $\begin{array}{l}\text { Increasenumber } \\
\text { of compound } \\
\text { leaves }\end{array}$ & $\begin{array}{l}\text { Increase } \\
\text { in height } \\
(\mathrm{cm})\end{array}$ & $\begin{array}{l}\text { Increase } \\
\text { number of } \\
\text { compound } \\
\text { leaves }\end{array}$ & $\begin{array}{l}\text { Increase } \\
\text { in } \\
\text { height } \\
(\mathrm{cm})\end{array}$ & $\begin{array}{l}\text { Increase } \\
\text { number of } \\
\text { compound } \\
\text { leaves }\end{array}$ \\
\hline $\begin{array}{c}\text { F }_{1} \text { Hybrid } \\
\text { Arjuna } \\
\text { Untreated } \\
\end{array}$ & $30 \pm 1.45$ & $10 \pm 1.01$ & $11 \pm 1.02$ & $7 \pm 0.08$ & $3 \pm 0.05$ & $13 \pm 1.07$ & $33 \pm 1.10$ & $10 \pm 1.03$ \\
\hline $\begin{array}{c}\text { Treated } \\
\text { Cow dung }\end{array}$ & $19 \pm 1.25$ & $9 \pm 0.02$ & $18 \pm 1.23$ & $8 \pm 0.06$ & $54 \pm 1.49$ & $19 \pm 1.04$ & $41 \pm 1.20$ & $16 \pm 1.07$ \\
\hline $\begin{array}{l}\text { Rabbit } \\
\text { manure }\end{array}$ & $18 \pm 1.24$ & $7 \pm 0.07$ & $15 \pm 1.13$ & $4 \pm 0.05$ & $42 \pm 1.55$ & $14 \pm 1.13$ & $28 \pm 1.21$ & $11 \pm 1.12$ \\
\hline $\begin{array}{l}\text { Chicken } \\
\text { Manure }\end{array}$ & $27 \pm 1.22$ & $10 \pm 1.09$ & $24 \pm 1.08$ & $9 \pm 0.09$ & $47 \pm 1.22$ & $15 \pm 1.07$ & $45 \pm 1.43$ & $14 \pm 1.15$ \\
\hline $\begin{array}{c}\text { Pahuza } \\
\text { S-22 } \\
\text { Untreated } \\
\end{array}$ & $28 \pm 1.26$ & $9 \pm 0.06$ & $17 \pm 1.11$ & $6 \pm 0.07$ & $35 \pm 1.26$ & $12 \pm 1.09$ & $30 \pm 1.28$ & $9 \pm 0.08$ \\
\hline $\begin{array}{c}\text { Treated } \\
\text { Cow dung }\end{array}$ & $17 \pm 1.09$ & $7 \pm 0.04$ & $16+1.09$ & $6 \pm 0.02$ & $47 \pm 1.29$ & $16 \pm 1.18$ & $36 \pm 1.46$ & $15 \pm 1.09$ \\
\hline $\begin{array}{l}\text { Rabbit } \\
\text { Manure }\end{array}$ & $26 \pm 1.31$ & $9+0.05$ & $16 \pm 1.03$ & $5 \pm 0.02$ & $46 \pm 1.23$ & $15 \pm 1.14$ & $24 \pm 1.20$ & $10 \pm 1.01$ \\
\hline $\begin{array}{l}\text { Chicken } \\
\text { Manure }\end{array}$ & $27 \pm 1.22$ & $8 \pm 0.07$ & $23 \pm 1.33$ & $8 \pm 0.09$ & $44 \pm 1.46$ & $14 \pm 1.16$ & $42 \pm 1.38$ & $13 \pm 1.15$ \\
\hline
\end{tabular}

Average of 3 replicates \pm Standard error.

A botanist [2] who had reported that mustard cake was found effective in reducing the incidence of Fusarium oxysporum f. sp. lycopersici. Neem cake was found as effective for the control of $F$. oxysporum f. sp. cubense in banana $[3,4]$.

Organic amendments increase the availability of nutrients besides improving physical condition of soil, increase the yield and reduce the soil-borne diseases [5]. Organic soil amendments have also been reported to be effective in controlling the pathogen [6-9]. The superiority of this amendment may be due to release of some inhibitory substances like nimbicidin, nimbin or azadirachtin on the decomposition, effecting the population of pathogen. Besides the nutrient content of these amendments may have a possible role in enhancing the host growth and vigour, increasing antagonistic microbial activity and enabling them to resist the attack of pathogen. 

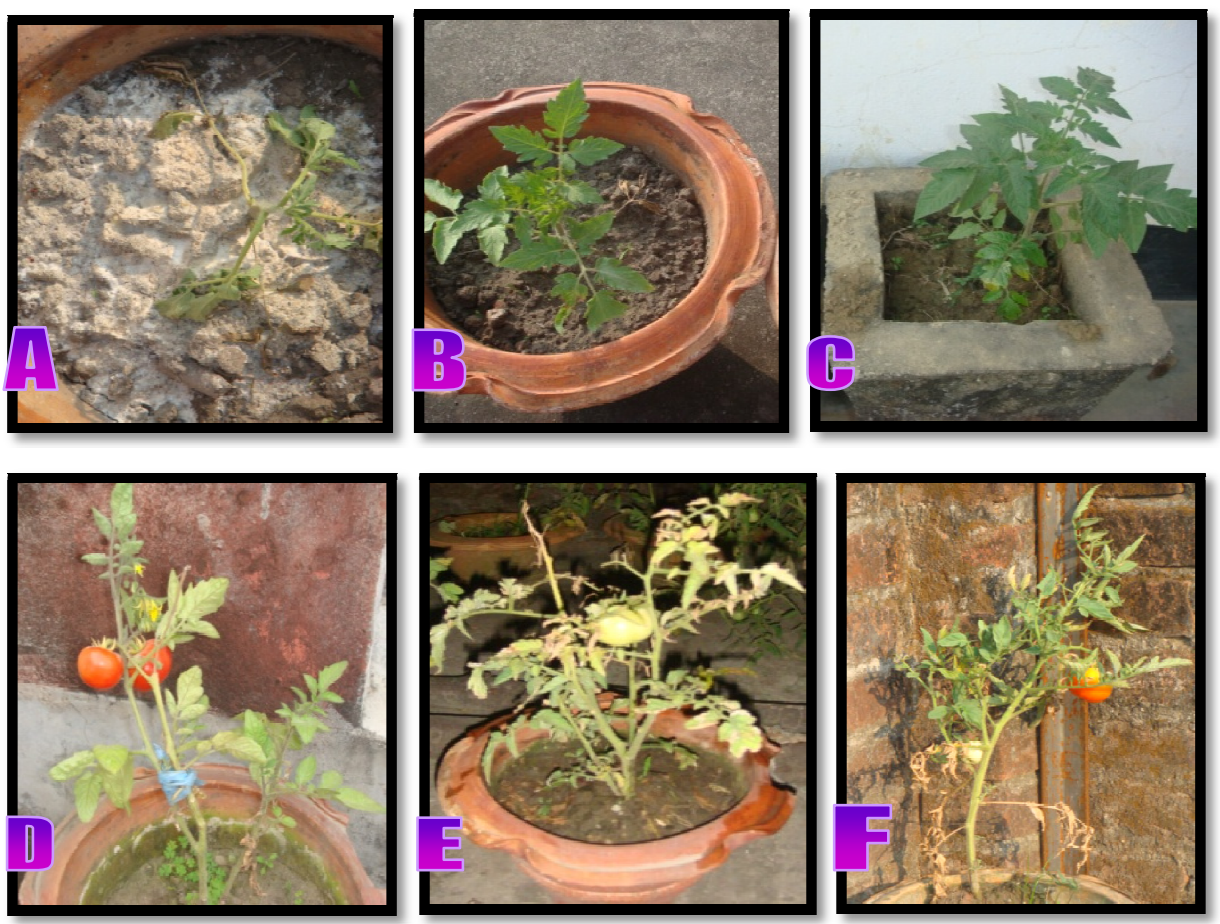

Plate 1 (Figures A-F): Tomato plants following treatment with biocontrol agent and organic amendments.

(A) Untreated inoculated with $S$. rolfsii.

(B \& C) Untreated healthy.

(D) Amended with cow dung manure.

(E) Amended with chicken manure.

(F) Amended with rabbit manure.

\section{Acknowledgment}

The author is thankful to University Grants Commission (UGC), Nepal for providing necessary support to pursue the research.

\section{References}

[1] Z. K. Punja, Annu. Rev. Phytopathol., 23 (1985) 97.

[1] B. Bhagawati, B.K. Goswami, C.S. Singh, Indian J. Nematol, 30 (2000) 16.

[3] A. Karthikeyan and Karunanithi, Pl. Dis. Res., 71 (1996) 180.

[4] G. Saravanan, S. Nanda, S. Sumitha, Pl. Dis. Res., 18 (2004) 35.

[5] S. Ramarethinam, B. Rajagopal, Pestology, 13 (1999) 21.

[6] VBS Nargund, Kulkarn, R.K. Hedge, Curr. Res., 13 (1984) 76.

[7] R.G. Linderman, Can. J. Pl Pathol., 11 (1989) 180.

[8] Y. Hadar, B. Golodeeki, Soil Bio. Biochem., 23 (1991) 303.

[9] S.A. Kulkarni, S. Kulkarni, Curr. Res., 24 (1995) 135. 